\title{
Growth hormone during in vitro fertilization in older women modulates the density of receptors in granulosa cells, with improved pregnancy outcomes
}

Article

Accepted Version

Creative Commons: Attribution-Noncommercial-No Derivative Works 4.0

Regan, S. L. P., Knight, P. G., Yovich, J. L., Arfuso, F. and Dharmarajan, A. (2018) Growth hormone during in vitro fertilization in older women modulates the density of receptors in granulosa cells, with improved pregnancy outcomes. Fertility and Sterility, 110 (7). pp. 1298-1310. ISSN 0015-0282 doi: https://doi.org/10.1016/j.fertnstert.2018.08.018 Available at https://centaur.reading.ac.uk/81147/

It is advisable to refer to the publisher's version if you intend to cite from the work. See Guidance on citing.

To link to this article DOI: http://dx.doi.org/10.1016/j.fertnstert.2018.08.018

Publisher: Elsevier

All outputs in CentAUR are protected by Intellectual Property Rights law, including copyright law. Copyright and IPR is retained by the creators or other copyright holders. Terms and conditions for use of this material are defined in the End User Agreement. 


\section{www.reading.ac.uk/centaur}

\section{CentAUR}

Central Archive at the University of Reading

Reading's research outputs online 
1 Growth hormone during in vitro fertilization in older women modulates

2 the density of receptors in granulosa cells, with improved pregnancy

3 outcomes.

4

5

6 Sheena L.P. Regan ${ }^{\mathrm{a} *}$, Phil G. Knight ${ }^{\mathrm{b}}$, John L.Yovich ${ }^{\mathrm{c}}$, ' Frank Arfuso ${ }^{\mathrm{a}}$, Arun Dharmarajan ${ }^{\mathrm{a}}$, 7

${ }^{\mathrm{a}}$ Stem Cell and Cancer Biology Laboratory, School of Biomedical Sciences, Curtin Health Innovation Research Institute, Curtin University, Perth, Australia. ' $\mathrm{S}$ School of Biological Sciences, Hopkins Building, University of Reading, Whiteknights, Reading RG6 6UB, UK. ${ }^{\mathrm{c}}$ PIVET Medical Centre, Perth, Australia.

\footnotetext{
* Dr Sheena LP Regan,
}

${ }^{a}$ Stem Cell and Cancer Biology Laboratory, School of Biomedical Sciences, Curtin Health Innovation Research Institute, Curtin University (CHIRI), Perth, Australia, GPO Box U1987, Perth, WA 6845, Australia

Email: sheenaregan@aapt.net.au 


\section{Introduction}

Ovarian depletion of primordial follicles is a continual natural process from gestation to adulthood, which culminates in the loss of ovarian function and which eventuates in the state of menopause (1, 2). When activated, the primordial follicles grow and develop into small antral follicles, the majority of which succumb to apoptosis $(3,4)$. At puberty, cyclic increases in circulating follicle stimulating hormone (FSH) recruit a cohort of small antral follicles at the start of each menstrual cycle $(3,5)$. The follicles grow under the influence of FSH, and express follicle stimulating hormone receptor (FSHR) and luteinizing hormone receptor (LHR). The activation of FSH and the FSHRs stimulates oestrogen synthesis, which subsequently stimulates proliferation of the granulosa cells and development of the oocyte. (6-9).

The ovulation rate is determined by the stage-specific decrease in pituitary secreted FSH, and results in follicles with insufficient LHRs that succumb to apoptosis (10-12). The follicle continues to grow until pre-ovulatory maturation when proliferation ceases and granulosa cell differentiation occurs in preparation for ovulation of the oocyte.

As the ovarian reserve of primordial follicles is depleted over the reproductive lifespan, regulation of folliculogenesis is altered, which results in decreased fertility (13). Ovarian depletion can be indirectly measured by the number of small antral follicles present at the beginning of a cycle, and is highly correlated to chronological age (14). During IVF treatment, high doses of recombinant human (r) FSH are administered to recruit more of the small antral follicles, and to maintain their growth during pituitary FSH down-regulation (15).

Infertility patients with a poor ovarian reserve have fewer small antral follicles available for recruitment, and higher doses of $\mathrm{rFSH}$ are used but with diminishing effectiveness in recruiting more follicles during IVF cycles. In an attempt to improve the pregnancy rate, patients have been offered co-treatment with growth hormone $(\mathrm{GH})(15,16)$. The patients with a poor response to $\mathrm{rFSH}$ treatment represent a large group of patients with critically diminishing ovarian reserve $(17,18)$. The challenge remains to identify the changes taking place as the ovarian reserve declines, and to find alternative stimulation to provide high quality oocytes for fertilisation.

Earlier studies showed GH treatment in vivo and in vitro, in conjunction with rFSH increased oocyte survival rate and pregnancy rate (19-22). The granulosa cells, including cumulus cells, as well as the oocyte of antral follicles express growth hormone receptor (GHR) and are therefore able to react to pituitary-derived or ovarian sources of $\mathrm{GH}(23,24)$. With regard to the latter, granulosa cells and the oocyte, but not cumulus and theca cells, have been shown to express GH mRNA (23-27). GHRs are activated by $\mathrm{GH}$, which changes the conformation of the receptor, promoting formation of a complex 
with janus kinase (JAK)2 (28). The GHR-JAK2 complex can elicit numerous cellular responses in the body, such as cell differentiation and oocyte maturation in the ovary (29).

The cellular mechanism underpinning the GH-induced improvement in oocyte quality and reduced miscarriage rate has not been reported in human studies. However, many attempts have been made to delineate the indirect changes taking place to serum and follicular fluid hormone levels. Previously, we have presented comprehensive results on the granulosal cell surface receptor density profiles of patients during ovarian ageing $(30,31)$. Ovarian granulosa cell receptor expression was found to fluctuate at the two critical times of dominant follicle selection and again at the terminal end of folliculogenesis in preparation for ovulation. Lower levels of receptor density and a reversal of this regulatory pattern was associated with reduced fertility and ovarian reserve in older patients. In the present study, we report the granulosal GHR density in different sized follicles from IVF patients undergoing conventional ovarian stimulation, with $\mathrm{rFSH}$ alone and with $\mathrm{rFSH}$ combined with GH cotreatment in young compared to older women with a reduced ovarian reserve. In addition, we report the granulosal FSHR, LHR, and BMPR1B receptor density in older, poor ovarian reserve patients treated with GH.

\section{Materials and Methods}

\section{Patients}

Patients (women) were selected randomly in a prospective regimen, and aged between 23 and 45 years, with a range of infertility factors, but limited to exclude unusual medical conditions, endocrine dysfunction, polycystic ovarian syndrome and endometriosis. Infertility issues were comprised of male factor, low ovarian reserve, donor sperm or unexplained fertility; and fertilisation was via intracytoplasmic sperm injection (ICSI). A total of 483 follicles were collected from 64 patients undergoing standard fertility treatment at PIVET Medical Centre Perth, Western Australia, (Table 1).

\section{Human IVF: Ovarian stimulation, follicular fluid, and oocyte}

Patient treatment consisted of two types of gonadotrophin releasing hormone-LH suppression (Orgalutran; MSD and Cetrotide; Merck Serono) in conjunction with commercially prepared recombinant human (r) FSH (Puregon; MSD and Gonal-f; Merck Serono), from cycle day 2 for $\sim 10$ days, as described by Regan et al. (2015). Ovulation was triggered with 10000 IU human chorionic gonadotrophin (hCG: Pregnyl; MSD), and oocyte retrieval was 36 hours later by transvaginal oocyte aspiration (30). Patients classified as poor prognosis due to poor ovarian response or with three or more failed attempts to conceive through IVF treatment with gonadotrophin alone, were co-treated with a total of 60 IU GH (Saizen, Serono, Australia) over a period of 20-24 days in the lead-up to IVF. GH was administered to 11 patients starting on day 21 of the previous cycle, and on day 2, 6, 8, 
10 , and 12 (10 IU per injection, a total of $60 \mathrm{IU}$ ) of the current cycle to women aged $\geq 39$ years who had at least one failed IVF cycle (15).

\section{Antral follicle count}

Patients received daily $\mathrm{rFSH}$ according to a long established algorithm based on the patient's profile of age and ovarian reserve in order to determine the $\mathrm{rFSH}$ dose required to stimulate 8-12 preovulatory follicles, (32). Ovarian reserve was measured indirectly by the antral follicle count, and was defined as the number of follicles between 2-10 $\mathrm{mm}$ in diameter, combining the number collected from both ovaries; that were present on $\sim$ day 5 of a preliminary assessment cycle, without rFSH (14). The patients were divided by age and ovarian reserve into groups based on the algorithm, as described previously by Regan et al. (2016) and a well-established clinical practice of patient treatment $(32,33)$ : Group $\mathrm{A}+=30-39$ small follicles; group $\mathrm{A}=20-29$ small follicles; group $\mathrm{B}=13$ 19 small follicles; group $\mathrm{C}=9-12$ small follicles, group $\mathrm{D}=5-8$ small follicles; group $\mathrm{E}=\leq 4$ small follicles.

\section{Immunolabelling of granulosa cells}

The ovarian follicles studied ranged in diameter from 4 to $27 \mathrm{~mm}$, and an average of $\sim 8000$ granulosa cells per individual follicle were analysed. Cell surface-expressed mature GHR protein density was measured by immunofluorescent labelling and flow cytometry. The diameter of the follicle was calculated using ultrasonography as described previously $(30,31,34)$. Flushing of the follicle (Quinn's Advantage with Hepes, Sage Media, Pasadena, California) removed the loosely attached layers of granulosa cells. Aliquots of suspended granulosa cells $\left(1 \times 10^{6}\right.$ cells in $\left.100 \mu \mathrm{l}\right)$ were immunolabelled and incubated separately with an optimised concentration of $4 \mu \mathrm{g} / \mathrm{ml}$ affinity purified polyclonal antibody to bone morphogenetic hormone receptor (BMPR1B), FSHR, LHR or GHR for 25 min at $5{ }^{\circ} \mathrm{C}$.

$3 \mathrm{D}$ image analysis using immunofluorescence detection has established the specificity of the antibodies in sheep, polyclonal goat anti-BMPR1B (sc-5679), goat anti-FSHR (sc-7798), and goat anti-LHR (sc-26341) (Santa Cruz Biotechnology, Santa Cruz, CA, USA), (35); and GHR (AF1210; Life Technologies, Victoria, Australia) (36). In addition, use of these antibodies has been previously reported in human studies (37-44) and for use in flow cytometry (38). The cells were washed with PBS and centrifuged at $300 \mathrm{~g}$ at $5^{\circ} \mathrm{C}$ for $5 \mathrm{~min}$. To render a homogeneous population of granulosa cells the monoclonal antibody CD45 was added to BMPR1B, GHR, and LHR tubes to enable the subtraction of the positive leukocyte common antigen $(\sim 3 \%)$ not removed during isolation of the granulosa cells with the ficoll gradient (555485; BD Biosciences, Perth, Australia), (Fig. 1A and 1B). 
143 Unstained samples or the substitution of a primary antibody with pre-immune goat IgG (Millennium

144 Science, Surrey Hills, Victoria Australia) at the same concentration as the primary antibody served as 145 a negative control for auto-fluorescence (Fig. 1A). A blocking peptide for FSH receptor and bone 146 morphogenetic protein receptor 1B indicated nonspecific binding applied to human granulosa cells 147 (sc-7798P, sc-5679P; Millennium Science, Surrey Hills, Victoria Australia), (Fig. 1B), and as 148 previously published $(37,38)$. Pre-absorbed LH (Lutropin, Merck Serono, Frenchs Forest, NSW,

149 Australia), and GH (Saizen, Merck Serono, Australia) also confirmed binding specificity. In the

150 current study, the 'normal' goat IgG and unstained control cells emitted an average mean fluorescent

151 intensity (MFI) that was classified as non-specific auto-fluorescence. The auto-fluorescence and the 152 nonspecific binding determined by the unstained control for each follicle was subtracted from each 153 follicle (Fig. 1B), and as described previously $(30,31)$.

154 Re-suspended $10 \mu 1$ aliquots of GHR immunolabelled, live granulosa cells were placed on slides and 155 visualized using an Olympus DP 70 camera fitted to an Olympus BX-51 upright fluorescent 156 microscope with a 40x UPlan N 0.4 N.A. objective (Olympus Imaging Australia, Macquarie Park, 157 Australia), (Fig.1C). Fluorescent microscopy revealed a positive staining of the cell membrane158 bound GHR as an intermittent, bright, ring-like pattern around the cells (Fig .1C). Pre-absorbed GH 159 was used as a negative control. A pure granulosa cell population was identified by graphing forward 160 scatter to remove doublets (FSC-H verses FSC-A), as previously described $(30,31,34)$. The uniform 161 granulosa cell population revealed positive staining for FSHR, which is unique to granulosa cells 162 (45). The data were analysed using FlowJo software (Tree Star Inc., Oregon, USA).

\section{Serum and Follicular fluid assessment}

165 The peak oestrogen concentration in serum was used to predict the follicular health of the follicle as 166 opposed to the serum levels collected at the time of follicle aspiration. Serum was analysed using 167 biochemical analysis on the days leading up to collection and on the day of collection. IVF patients 168 undergoing treatment were examined in a natural cycle and during exogenous rFSH stimulated 169 cycles. Follicular fluid collected from follicles 17 to $23 \mathrm{~mm}$ were analysed for testosterone, FSH, and 170 LH using a random access immunoassay system (Siemens Medical Solutions, Bayswater, Victoria, 171 Australia). Follicular fluid, testosterone, FSH, and LH were analysed undiluted, whereas oestrogen 172 and progesterone were diluted manually 1:1000 with a multi-diluent and, when required, a further 173 manual dilution of progesterone $10 \mathrm{x}$ and oestrogen; $5 \mathrm{x}$. Percentage coefficient of variance $(\mathrm{CV})$ for 174 a concentration range $137.4 \mathrm{pmol} / \mathrm{L}$ to $3257 \mathrm{pmol} / \mathrm{L}$ was oestrogen $=5.2 ; \mathrm{LH}=3.9 ; \mathrm{FSH}=2.9$; 175 testosterone $=5.9 ;$ progesterone $=9.4$.

178 Mean fluorescent intensity was obtained using $\sim 8000$ granulosa cells per individual follicle for the direct measurement of receptor protein expression. The data were subjected to statistical verification 
using one-way ANOVA with an uncorrected Fisher's LSD for follicular size using GraphPad Prism 6. Values in graphs are means \pm S.E.M., and differences were considered significant if $* \mathrm{p}<0.05$, ${ }^{* *} \mathrm{p}<0.01,{ }^{* * *} \mathrm{p}<0.005$, and $* * * * \mathrm{p}<0.001$. The letter, such as 'a', signifies a statistical significant difference to the matching letter (e.g. ' $\mathrm{a}^{*}$ '). The attached asterisk $\left(\mathrm{a}^{*}\right)$ indicates the significance level for the size follicle. A two tailed, student t-test and chi squared was also used.

\section{Human Ethics}

Patients undergoing standard fertility treatment at PIVET Medical Centre, Perth, Australia provided informed consent according to Curtin University Human Research Committee (HR RD26-10:2010 and 2016); and all methods were performed in accordance with the relevant guidelines and regulations under State Legislation and National Accreditation processes.

\section{Results}

\section{GHR density without growth hormone co-treatment and ovarian reserve depletion}

In the youngest patients with good ovarian reserve, a constant level of granulosal GHR was expressed during follicular growth in both the A+ and A groups, both of which are typical for a patient in this age group (Fig. 2A).

GHR density was significantly decreased as the ovarian reserve was depleted in all of the three older age groups. In the 31-34 y patient group, GHR density on the granulosa cells from follicles of the same size was significantly reduced in the patients with a reduced ovarian reserve for the age group ( $\mathrm{p}=0.039,14 \mathrm{~mm}$ follicles; $0.0037,16 \mathrm{~mm}$ follicles, Fig. 2B). This trend was also found in the 35-38 y patient group; $(\mathrm{p}=0.029,4 \mathrm{~mm}$ follicles; Fig. $2 \mathrm{C}$ ) and in the $39+\mathrm{y}$ patient group $(\mathrm{p}=0.0001,4 \mathrm{~mm}$ follicles; $\mathrm{p}=0.001214 \mathrm{~mm}$ follicles, Fig. 2D). In the older patients $(39+y)$, with a comparatively better ovarian reserve of B or C, the level of GHR was significantly reduced in the larger follicles to the level observed in the poorer $\mathrm{D}$ and $\mathrm{E}$ ovarian reserve group ( $<<0.001 ;$ Fig. $2 \mathrm{D})$.

\section{GHR receptor density profile independent of patient age}

The patient data were analysed based on ovarian follicle reserve, independent of chronological age (Suplemetary Fig. 1). In patients with good ovarian reserve, an initial high level of GHR in the smaller follicles was followed by a decline as the follicles increased in size (14 to $23 \mathrm{~mm}$ follicles, $\mathrm{p}=0.0005)$. This pattern was reversed in the poorer ovarian reserve patient groups of $\mathrm{D} \& \mathrm{E}(\mathrm{p}<0.05)$. Granulosal GHR receptor density was greater in the $10 \mathrm{~mm}(\mathrm{p}<0.01)$ and $14 \mathrm{~mm}(\mathrm{p}<0.005)$ follicles in the good ovarian reserve patient group compared to patients with the poorest ovarian reserve (Suplemetary Fig. 1).

\section{Growth hormone co-treatment restores preovulatory down-regulation of FSHR BMPR1B and LHR}


The level of GHR was significantly increased in IVF patients receiving GH co-treatment in follicles from 10 to $23 \mathrm{~mm}$ compared to the same age patients of $39+\mathrm{y}$ with an ovarian reserve of D \& $\mathrm{E}$ $(\mathrm{p}<0.01$ to $\mathrm{p}<0.001$, Fig.3A). The level of GHR expression in different sized follicles was not significantly different in patients treated with GH (Fig 4A).

The level of FSHR was significantly increased in IVF patients receiving GH in $16 \mathrm{~mm}$ follicles compared to the same age patients of $39+y$ with an ovarian reserve of D \& E without $\mathrm{GH}(\mathrm{p}<0.001$, Fig.4B). The level of FSHR in GH treated patients was also increased in the larger follicles from 4 $\mathrm{mm}$ to $16 \mathrm{~mm}$ (Fig. 3B, p<0.005). This was followed by a significant down-regulation of the largest preovulatory follicles $(\mathrm{p}<0.01,19 \mathrm{~mm})$.

The level of LHR was significantly increased in IVF patients receiving GH in $16 \mathrm{~mm}$ follicles compared to the same age patients of $39+y$ with an ovarian reserve of D \& E without GH $(p<0.005$, Fig.4C). The LHR density of the granulosa cells collected from patients who received GH cotreatment during an IVF cycle was also significantly elevated in the 10 to $16 \mathrm{~mm}$ follicles $(\mathrm{p}<0.01$, Fig. 3C). In contrast to the untreated group, GH co-treated patients showed down-regulation of granulosal LHR density in follicles between 16 and $19 \mathrm{~mm}$ in diameter ( $<0.005$, Fig. 3C).

The level of BMPR1B was significantly increased in IVF patients receiving GH in $10 \mathrm{~mm}, 14 \mathrm{~mm}$ and $16 \mathrm{~mm}$ follicles compared to the same age patients of $39+\mathrm{y}$ with an ovarian reserve of D \& $\mathrm{E}$ without GH ( $<<0.001, \mathrm{p}<0.005, \mathrm{p}<0.05$, respectively; Fig.4D).

Granulosal BMPR1B density was significantly higher in $10 \mathrm{~mm}$, follicles from the GH co-treated patients compared to the larger pre-ovulatory follicles of either $16 \mathrm{~mm}$ or $19 \mathrm{~mm}$ ( $\mathrm{p}<0.05$, Fig. 3D). In contrast, to the untreated group, GH co-treated patients showed down-regulation of granulosal BMPR1B density in the largest follicles of 16 to $19 \mathrm{~mm}(\mathrm{p}<0.05, \mathrm{p}<0.05$, respectively; Fig. 3D)

When the follicles sizes are combined, the average granulosal density for GHR, FSHR, LHR and BMPR1B was significantly higher in the GH treated group with the same ovarian reserve and age (Fig. 3 A-D Inset, $\mathrm{p}<0.005$ ).

\section{Growth hormone co-treatment and pregnancy rate in IVF patients}

The number of pregnancies was calculated based on the number of embryos that were transferred to the patients, which included subsequent FET cycles of cryo preserved embryos.

The number of FET cycles was not significantly different between groups of patient. There was a significant difference in the pregnancy rate in GH treated patients compared to the same age and ovarian reserve patients without GH co-treatment ( $\mathrm{p}=0.003$; Fig. 5.). The number of live births per 
embryo transfer was also significantly greater in the GH co-treated older age group compared to the equivalent age and ovarian reserve ( $\mathrm{p}=0.0406$, Fig. 6). The level of oestrogen and progesterone in serum and follicular fluid was not significantly different when comparing GH treatment in the equivalent older patient group of $39+\mathrm{y}$.

\section{Serum \& Follicular Fluid \& GH co-treatment}

The results from the current study indicate that the GH co-treatment did not alter the oestrogen level of the 39+ year group cohort with an ovarian reserve of D or E during an IVF cycle (Supplementary Fig 2A). Furthermore, neither the ratio of oestrogen was not altered, nor the levels of oestrogen secreted, based on either the total number of follicles or the number of follicles greater than $14 \mathrm{~mm}$ present in the ovary at the time of collection, which were not significantly different. In addition, the follicular fluid concentration of oestrogen, progesterone, FSH, or testosterone was not significantly different to the age matched patients with a similar ovarian reserve that were co-treated with GH (Supplementary Fig 2B).

\section{Discussion}

GHRs are predominantly found on the granulosa cell membrane surface and in the endoplasmic reticulum, and to a lesser degree, but commonly, in the nuclear membrane of highly prolific cells (46, 47). The GHR is regulated by GH binding proteins, which are secreted from the GHR, and by other growth factors indirectly such as FSH, BMPs and somatostatin $(48,49)$. In the current study, GH treatment induced a direct change to the receptor expression of GHR itself and indirectly to the other receptors FSHR, LHR and BMPR1B.

In support of the clinical data on ageing, human granulosa receptor density and dysregulation of FSHR, LHR and BMPR1B has been associated with ovarian depletion and reduced fertility $(30,31)$. We now provide additional data in support of a reversal of the dysregulated receptor expression observed in older patients that occurs when they are treated with GH. In addition, depletion of the ovarian reserve was accompanied by a reduction in GHR density, whereas GH co-treatment during IVF increased the receptor density in older women who had a reduced ovarian reserve. These findings provide a possible cellular regulatory mechanism involved in the poor pregnancy and live birth rate in the older 39-45 y patients and reported by others $(15,16,50-55)$ and reviewed by $(56-$ $58)$.

Evidence from our previously published work and the current study suggest that ovarian reserve and age are associated with reduced and dysregulated levels of receptor expression on granulosa cells. Therefore, the influence of age and ovarian reserve of subjects or animals needs to be considered as a confounding variable in previous studies. In heifers, GH may not have resulted in any change to FSH and LH receptor binding because the cows were young, with an uncompromised ovarian reserve 
and a sufficient receptor density (59). The effect of GH co-treatment on receptor density in patients with a good ovarian reserve for age remains at this time unknown.

While GH increased the receptor expression on granulosa cells from the larger follicles, it had no effect on the FSHR and LHR density at the critical time of dominant follicle selection (smallest follicles of $4 \mathrm{~mm}$ ). Previously, a poor ovarian response to $\mathrm{rFSH}$ stimulation has been associated with reduced granulosal FSHR expression (37). However, GH co-treatment was found not to alter the FSHR density in small bovine follicles, which is consistent with our findings for small human follicles (60). The lack of effect on FSHR and LHR expression of small pre-ovulatory follicles may explain why the number of oocytes collected was not increased in the current human model and others (56).

Conversely, animal studies have reported an increase in oocyte number (61-65) . For example, even though more small bovine antral follicles were produced after 45 days of GH treatment in a natural cycle, the granulosal FSHRs and LHRs from pre-ovulatory bovine follicles were not affected (59, 60). This is surprising; however, the receptor binding studies were determined only for the three largest follicles from each cow. Therefore, the expected pre-ovulatory down-regulation of these large follicles would have reduced FSHR expression which would confound these results. Added to this the receptor binding was not measured in any of the smaller follicles. In other studies, GH treatment increased the receptors in the rat (66) however; in the pig the receptor expression was reduced (67). In our human model, small antral follicles had high levels of FSHR followed by down-regulation which coincides with dominant follicle selection. The high level of FSHRs induce LHR expression in a natural cycle to ensure recruitment to the dominant cohort of follicles (68). In a natural cycle, pituitary secreted FSH is reduced at this critical time, whereas in an IVF cycle; rFSH is abundant; therefore the densities of the gonadotrophin receptors (FSHR and LHR) are pivotal in regulating follicle growth and dominance.

Patients with a reduced ovarian reserve have a poorer response to rFSH treatment in IVF, and produce oocytes of poorer quality (37). The poor responder group of patients also have an associated high risk of foetal aneuploidy that has been correlated to ovarian reserve (69). Recently published data have shown that GH co-treatment increases the pregnancy rate by a suggested improvement in oocyte quality, rather than the quantity of follicles recruited $(15,16)$.

If the oocyte number is not significantly different in the GH treated older women, then the focus shifts to the effect of GH on the quality of the oocyte. Regulation of proliferation, steroid production, luteinisation, ovulation, and recommencement of meiosis fundamentally resides with the functional expression of receptors in the follicle cells and oocyte. 
A decline in granulosal BMPR1B and FSHR density occurred at the time of cyclic dominant follicle selection, and again during the terminal stage of folliculogenesis, in young (23-30 years) IVF patients with good ovarian reserve $(30,31)$. Older patients $(39+$ years) with poor ovarian reserve experienced a reversal of this pattern $(30,31)$. In addition, the LHR density failed to be down-regulated during pre-ovulatory maturation in the $39+$ year group, and was reduced with ovarian reserve (31).

In the present study, we report increased granulosa cell GHR density in different sized follicles from IVF patients undergoing conventional ovarian stimulation in young compared to older women with a reduced ovarian reserve. In addition, we report increased granulosal GHR, FSHR, LHR, and BMPR1B receptor density in older, poor ovarian reserve patients treated with GH. Importantly, the women treated with GH demonstrated receptor expression down-regulation in the largest follicles. The down-regulation would be essential for maturation of the ovulatory follicles, luteinisation and a shift to the luteal phase.

In addition, the increased granulosal LHR density observed in the GH co-treated patients would have the potential to increase the sensitivity during the hCG/LH surge to trigger final maturation and ovulation of the oocyte $(70,71)$. The improved sensitivity may give rise to improved oocyte quality and live birth rate. In support of the link between receptor density and maturation, a previous electron microscopy study revealed that oocytes that did not fertilise had reduced levels of granulosal luteinisation and were less responsive to hCG, which binds to the LHR (72).

\section{Conclusion}

The complexity and limitations of a largely observational, in vivo study in humans makes it difficult to define the cellular mechanism through which numerous growth factors and pathways contribute to the regulation of follicular growth and differentiation. However, the present study has generated evidence suggesting several cellular mechanisms that could contribute to the improved oocyte quality observed in GH co-treated IVF patients with a poor ovarian reserve.

GH co-treatment increased granulosal GHR density that would increase GHR-JAK-STAT activity, and result in an increase in the intermediate products of transcription. This, in turn, could be mechanistically linked to the corresponding increase in gonadotrophin receptors and BMPR1B density observed in GH co-treated patients. GH co-treatment did not alter the gonadotrophin receptor density of the small follicles, and would therefore account for the lack of improvement in the number of follicles recruited during dominant follicle selection.

In contrast, GH co-treatment also restored the pre-ovulatory down-regulation of FSHR, BMPR1B and LHR density, which may improve the maturation process of luteinisation in GH co-treated patients with reduced ovarian reserve. Combined with the latter, an increase in LHR density may 
improve follicle development and provide another possible cellular mechanism responsible for the improved pregnancy and live birth rate. Objectively, we remain uncertain whether the beneficial action is mediated via improved oocyte quality or other responses such as endometrial receptivity.

\section{Acknowledgements}

The authors thank all the participants who generously donated their samples to this study, the clinical doctors, embryologists, and nursing staff.

\section{Authors' roles}

SLPR conceived the study, experimental design, conducted all experiments, the analysis and interpretation of data, wrote the first draft of the manuscript and the final version of the paper. Obtained informed consent from patients and ethics approval. PK supervised, interpretation of data, contributed to the draft of the manuscript, interpretation of data, and critically revised the manuscript. JLY supervised, participated in the study design, participated in obtaining granulosa cells, interpretation of data, and critically revised the manuscript. FA supervised, contributed to the draft of the manuscript, interpretation of data, and critically revised the manuscript. AD supervised, participated in the study design, interpretation of data, contributed to the draft of the manuscript, and critically revised the manuscript.

\section{Funding}

S.L.P.R. was a recipient of an Australian Postgraduate Award. This work was supported by additional private external funding, which was gratefully accepted from Denby Macgregor.

\section{Conflict of interest}

The authors declare that there is no conflict of interest that could be perceived as prejudicing the impartiality of the research reported.

\section{References}

1. Gougeon A. Dynamics of follicular growth in the human: a model from preliminary results. Hum Reprod 1986;1:81-7.

2. Richards JS. Hormonal Control of Gene Expression in the OVary. Endocrine Reviews 1994;15:725-51.

3. Ginther OJ, Beg MA, Gastal EL, Gastal MO, Baerwald AR, Pierson RA. Systemic concentrations of hormones during the development of follicular waves in mares and women: a comparative study. Reproduction 2005;130:379-88.

4. Hillier SG. Gonadotropic control of ovarian follicular growth and development. Molecular and Cellular Endocrinology 2001;179:39-46.

5. Austin EJ, Mihm M, Evans ACO, Knight PG, Ireland JLH, Ireland JJ et al. Alterations in Intrafollicular Regulatory Factors and Apoptosis During Selection of Follicles in the First Follicular Wave of the Bovine Estrous Cycle. Biology of Reproduction 2001;64:839-48.

6. Campbell BK, Dobson H, Baird DT, Scaramuzzi RJ. Examination of the relative role of FSH and LH in the mechanism of ovulatory follicle selection in sheep. Journal of reproduction and fertility 1999;117:355-67.

7. Ginther OJ, Khan FA, Hannan MA, Rodriguez MB, Pugliesi G, Beg MA. Role of LH in luteolysis and growth of the ovulatory follicle and estradiol regulation of LH secretion in heifers. Theriogenology 2012;77:1442-52.

8. Luo W, Gumen A, Haughian J, Wiltbank M. The role of luteinizing hormone in regulating gene expression during selection of a dominant follicle in cattle. Biology of Reproduction 2011;84:369-78. 
413 9. Picton HM, McNeilly AS. Evidence to support a follicle-stimulating hormone threshold

414 theory for follicle selection in ewes chronically treated with gonadotrophin-releasing hormone

415 agonist. Journal of reproduction and fertility 1991;93:43-51.

416 10. Minegishi T, Tano M, Abe Y, Nakamura K, Ibuki Y, Miyamoto K. Expression of luteinizing

417 hormone/human chorionic gonadotrophin (LH/HCG) receptor mRNA in the human ovary. Molecular

418 Human Reproduction 1997;3:101-7.

419 11. Mihm M, Baker PJ, Ireland JLH, Smith GW, Coussens PM, Evans ACO et al. Molecular

420 Evidence That Growth of Dominant Follicles Involves a Reduction in Follicle-Stimulating Hormone

421 Dependence and an Increase in Luteinizing Hormone Dependence in Cattle. Biology of Reproduction $422 \quad 2006 ; 74: 1051-9$.

423 12. Yung Y, Aviel-Ronen S, Maman E, Rubinstein N, Avivi C, Orvieto R et al. Localization of 424 luteinizing hormone receptor protein in the human ovary. Molecular Human Reproduction $425 \quad 2014 ; 20: 844-9$.

426 13. Klein NA, Battaglia DE, Fujimoto VY, Davis GS, Bremner WJ, Soules MR. Reproductive 427 aging: accelerated ovarian follicular development associated with a monotropic follicle-stimulating hormone rise in normal older women. The Journal of Clinical Endocrinology \& Metabolism 1996;81:1038-45.

430 14. Hansen KR, Hodnett GM, Knowlton N, Craig LB. Correlation of ovarian reserve tests with 431 histologically determined primordial follicle number. Fertility and Sterility 2011;95:170-5.

432 15. Yovich JL, Stanger JD. Growth hormone supplementation improves implantation and 433 pregnancy productivity rates for poor-prognosis patients undertaking IVF. Reproductive 434 BioMedicine Online 2010;21:37-49.

435 16. Tesarik J, Hazout A, Mendoza C. Improvement of delivery and live birth rates after ICSI in 436 women aged $>40$ years by ovarian co-stimulation with growth hormone. Human Reproduction $437 \quad 2005 ; 20: 2536-41$.

438 17. de Ziegler D, Streuli I, Meldrum D, Chapron C. The value of growth hormone supplements

439 in ART for poor ovarian responders. Fertility and Sterility 2011;96:1069-76.

440 18. Kyrou D, Kolibianakis E, Venetis C, Papanikolaou E, Bontis J, Tarlatzis B. How to improve

441 the probability of pregnancy in poor responders undergoing in vitro fertilization: a systematic review 442 and meta-analysis. Fertility and Sterility 2009;91:749-66.

443 19. Folch J, Ramon JP, Cocero MJ, Alabart JL, Beckers JF. Exogenous growth hormone

444 improves the number of transferable embryos in superovulated ewes. Theriogenology 2001;55:177785.

20. Barreca A, Artini PG, Del Monte P, Ponzani P, Pasquini P, Cariola G et al. In vivo and in vitro effect of growth hormone on estradiol secretion by human granulosa cells. Journal of Clinical Endocrinology \& Metabolism 1993;77:61-7.

21. Izadyar F, Colenbrander B, Bevers MM. In vitro maturation of bovine oocytes in the presence of growth hormone accelerates nuclear maturation and promotes subsequent embryonic development. Molecular reproduction and development 1996;45:372-7.

22. Izadyar F, Zeinstra E, Bevers MM. Follicle-stimulating hormone and growth hormone act differently on nuclear maturation while both enhance developmental competence of in vitro matured bovine oocytes. Molecular reproduction and development 1998;51:339-45.

23. Izadyar F, Zhao J, Van Tol HT, Colenbrander B, Bevers MM. Messenger RNA expression and protein localization of growth hormone in bovine ovarian tissue and in cumulus oocyte complexes (COCs) during in vitro maturation. Molecular reproduction and development 1999;53:398-406.

24. Abir R, Garor R, Felz C, Nitke S, Krissi H, Fisch B. Growth hormone and its receptor in human ovaries from fetuses and adults. Fertility and Sterility 2008;90:1333-9.

25. Izadyar F, Hage WJ, Colenbrander B, Bevers MM. The promotory effect of growth hormone on the developmental competence of in vitro matured bovine oocytes is due to improved cytoplasmic maturation. Molecular reproduction and development 1998;49:444-53.

26. Izadyar F, Van Tol HT, Colenbrander B, Bevers MM. Stimulatory effect of growth hormone on in vitro maturation of bovine oocytes is exerted through cumulus cells and not mediated by IGF-I. Molecular reproduction and development 1997;47:175-80.

468 27. Bevers MM, Izadyar F. Role of growth hormone and growth hormone receptor in oocyte maturation. Molecular and Cellular Endocrinology 2002;197:173-8. 
28. Lan H, Li W, Fu Z, Yang Y, Wu T, Liu Y et al. Differential intracellular signalling properties of the growth hormone receptor induced by the activation of an anti-GHR antibody. Molecular and Cellular Endocrinology 2014;390:54-64.

29. Waters MJ, Hoang HN, Fairlie DP, Pelekanos RA, Brown RJ. New insights into growth hormone action. Journal of molecular endocrinology 2006;36:1-7.

30. Regan SLP, Knight PG, Yovich J, Stanger J, Leung Y, Arfuso F et al. Dysregulation of granulosal bone morphogenetic protein receptor $1 \mathrm{~B}$ density is associated with reduced ovarian reserve and the age-related decline in human fertility. Molecular and Cellular Endocrinology 2016;425:84-93.

31. Regan SLP, Knight PG, Yovich JL, Stanger JD, Leung Y, Arfuso F et al. Infertility and ovarian follicle reserve depletion are associated with dysregulation of the FSH and LH receptor density in human antral follicles. Molecular and Cellular Endocrinology 2017;446:40-51. 32. Yovich J, Stanger J, Hinchliffe P. Targeted gonadotrophin stimulation using the PIVET algorithm markedly reduces the risk of OHSS. Reproductive BioMedicine Online 2012;24:281-92. 33. Yovich JL, Alsbjerg B, Conceicao JL, Hinchliffe PM, Keane KN. PIVET rFSH dosing algorithms for individualized controlled ovarian stimulation enables optimized pregnancy productivity rates and avoidance of ovarian hyperstimulation syndrome. Drug Design, Development and Therapy 2016;10:2561-73.

34. Regan SLP, Knight PG, Yovich JL, Stanger JD, Leung Y, Arfuso F et al. The effect of ovarian reserve and receptor signalling on granulosa cell apoptosis during human follicle development. Molecular and Cellular Endocrinology 2017.

35. Al-Samerria S, Almahbobi G. Three-dimensional image analysis to quantify the temprorosmacial expression of cellular receptors. Journal of Medical and Bioengineering 2014 3:179-82.

36. Weall BM, Al-Samerria S, Conceicao J, Yovich JL, Almahbobi G. A direct action for GH in improvement of oocyte quality in poor-responder patients. Reproduction 2015;149:147-54.

37. Cai J, Lou H, Dong M, Lu X, Zhu Y, Gao H et al. Poor ovarian response to gonadotropin stimulation is associated with low expression of follicle-stimulating hormone receptor in granulosa cells. Fertility and Sterility 2007;87:1350-6.

38. Gao S, De Geyter C, Kossowska K, Zhang H. FSH stimulates the expression of the ADAMTS-16 protease in mature human ovarian follicles. Molecular Human Reproduction 2007;13:465-71.

39. Pidoux G, Gerbaud P, Tsatsaris V, Marpeau O, Ferreira F, Meduri G et al. Biochemical characterization and modulation of $\mathrm{LH} / \mathrm{CG}$-receptor during human trophoblast differentiation. Journal of cellular physiology 2007;212:26-35.

40. Abir R, Ben-Haroush A, Melamed N, Felz C, Krissi H, Fisch B. Expression of bone morphogenetic proteins 4 and 7 and their receptors IA, IB, and II in human ovaries from fetuses and adults. Fertility and Sterility 2008;89:1430-40.

41. Haÿ E, Lemonnier J, Fromigué O, Guénou H, Marie PJ. Bone morphogenetic protein receptor ib signaling mediates apoptosis independently of differentiation in osteoblastic cells. Journal of Biological Chemistry 2004;279:1650-8.

42. Bozzola M, Zecca M, Locatelli F, Radetti G, Pagani S, Autelli M, Tatò L, Chatelain P. Evaluation of growth hormone bioactivity using the $\mathrm{Nb} 2$ cell bioassay in children with growth disorders. J Endocrinol Invest 1998 Dec;21(11):765-70.

43. Weall BM, Al-Samerria S, Conceicao J, Yovich JL, Almahbobi G. A direct action for growth hormone in improving oocyte quality in poor responder patients. Reproduction 2014.

44. Regan SLP, McFarlane JR, O'Shea T, Andronicos N, Arfuso F, Dharmarajan A et al. Flow cytometric analysis of FSHR, BMPR1B, LHR and apoptosis in granulosa cells and ovulation rate in merino sheep. Reproduction 2015; 150 151-63.

45. Hermann BP, Heckert LL. Transcriptional regulation of the FSH receptor: New perspectives. Molecular and Cellular Endocrinology 2007;260-262:100-8.

46. Brooks AJ, Wooh JW, Tunny KA, Waters MJ. Growth hormone receptor; mechanism of action. The International Journal of Biochemistry \& Cell Biology 2008;40:1984-9.

47. Zhu T, Goh ELK, Graichen R, Ling L, Lobie PE. Signal transduction via the growth hormone receptor. Cellular Signalling 2001;13:599-616.

48. Le Roith D, Bondy C, Yakar S, Liu J-L, Butler A. The Somatomedin Hypothesis: 2001. Endocrine reviews 2001;22:53-74. 
49. Nakamura E, Otsuka F, Inagaki K, Miyoshi T, Matsumoto Y, Ogura K et al. Mutual regulation of growth hormone and bone morphogenetic protein system in steroidogenesis by rat granulosa cells. Endocrinology 2012;153:469-80.

50. Kucuk T, Kozinoglu H, Kaba A. Growth hormone co-treatment within a GnRH agonist long protocol in patients with poor ovarian response: a prospective, randomized, clinical trial. Journal of Assisted Reproduction and Genetics 2008;25:123-7.

51. Suikkari A, MacLachlan V, Koistinen R, Seppälä M, Healy D. Double-blind placebo controlled study: human biosynthetic growth hormone for assisted reproductive technology. Fertil Steril 1996; Apr 65:800-5.

52. Keane KN, Yovich JL, Hamidi A, Hinchliffe PM, Dhaliwal SS. Single-centre retrospective analysis of growth hormone supplementation in IVF patients classified as poor-prognosis. BMJ Open $2017 ; 7$.

53. Eftekhar M, Aflatoonian A, Mohammadian F, Eftekhar T. Adjuvant growth hormone therapy in antagonist protocol in poor responders undergoing assisted reproductive technology. Arch Gynecol Obstet 2013;287:1017-21.

54. Levy T, Limor R, Villa Y, Eshel A, Eckstein N, Vagman I et al. Another look at cotreatment with growth hormone and human menopausal gonadotrophins in poor ovarian responders. Human Reproduction 1993;8:834-9.

55. Volpe A, Coukos G, Barreca A, Artini PG, Minuto F, Giordano G et al. Ovarian response to combined growth hormone-gonadotropin treatment in patients resistant to induction of superovulation. Gynecological Endocrinology 1989;3:125-33.

56. Homburg R, Singh A, Bhide P, Shah A, Gudi A. The re-growth of growth hormone in fertility treatment: a critical review. Human fertility 2012;15:190-3.

57. Kolibianakis EM, Venetis CA, Diedrich K, Tarlatzis BC, Griesinger G. Addition of growth hormone to gonadotrophins in ovarian stimulation of poor responders treated by in-vitro fertilization: a systematic review and meta-analysis. Human Reproduction Update 2009;15:613-22.

58. Kyrou D, Kolibianakis EM, Venetis CA, Papanikolaou EG, Bontis J, Tarlatzis BC. How to improve the probability of pregnancy in poor responders undergoing in vitro fertilization: a systematic review and meta-analysis. Fertility and Sterility 2009;91:749-66.

59. Gong JG, Bramley T, Webb R. The effect of recombinant bovine somatotropin on ovarian function in heifers: follicular populations and peripheral hormones. Biology of Reproduction 1991;45:941-9.

60. Garverick H, Baxter G, Gong J, Armstrong D, Campbell B, Gutierrez C et al. Regulation of expression of ovarian mRNA encoding steroidogenic enzymes and gonadotrophin receptors by FSH and GH in hypogonadotrophic cattle. Reproduction 2002;123:651-61.

61. Bachelot A, Monget P, Imbert-Bolloré P, Coshigano K, Kopchick JJ, Kelly PA et al. Growth Hormone Is Required for Ovarian Follicular Growth. Endocrinology 2002;143:4104-12.

62. Scaramuzzi RJ, Murray JF, Downing JA, Campbell BK. The effects of exogenous growth hormone on follicular steroid secretion and ovulation rate in sheep. Domestic animal endocrinology 1999;17:269-77.

63. Slot KA, Kastelijn J, Bachelot A, Kelly PA, Binart N, Teerds KJ. Reduced recruitment and survival of primordial and growing follicles in GH receptor-deficient mice. Reproduction 2006;131:525-32.

64. Gong JG, Baxter G, Bramley TA, Webb R. Enhancement of ovarian follicle development in heifers by treatment with recombinant bovine somatotrophin: a dose-response study. Journal of reproduction and fertility 1997;110:91-7.

65. Saccon TD, Moreira F, Cruz LA, Mondadori RG, Fang Y, Barros CC et al. Ovarian aging and the activation of the primordial follicle reserve in the long-lived Ames dwarf and the short-lived bGH transgenic mice. Molecular and Cellular Endocrinology 2017;455:23-32.

66. Jia X-C, Kalmijn J, Hsueh AJW. Growth Hormone Enhances Follicle-Stimulating HormoneInduced Differentiation of Cultured Rat Granulosa Cells. Endocrinology 1986;118:1401-9.

67. Spicer LJ, Klindt J, Buonomo FC, Maurer R, Yen JT, Echternkamp SE. Effect of porcine somatotropin on number of granulosa cell luteinizing hormone/human chorionic gonadotropin receptors, oocyte viability, and concentrations of steroids and insulin-like growth factors I and II in follicular fluid of lean and obese gilts. Journal of animal science 1992;70:3149-57.

68. Rice S, Ojha K, Whitehead S, Mason H. Stage-specific expression of androgen receptor, follicle-stimulating hormone receptor, and anti-müllerian hormone type ii receptor in single, isolated, 
582 human preantral follicles: Relevance to polycystic ovaries. The Journal of Clinical Endocrinology \& 583 Metabolism 2007;92:1034-40.

69. Grande M, Borobio V, Jimenez JM, Bennasar M, Stergiotou I, Peñarrubia J et al. Antral follicle count as a marker of ovarian biological age to reflect the background risk of fetal aneuploidy. Human Reproduction 2014;29:1337-43.

70. Greisen S, Ledet T, Ovesen P. Effects of androstenedione, insulin and luteinizing hormone on steroidogenesis in human granulosa luteal cells. Human Reproduction 2001;16:2061-5. 71. Donadeu F, Ascoli M. The Differential Effects of the Gonadotropin Receptors on Aromatase Expression in Primary Cultures of Immature Rat Granulosa Cells Are Highly Dependent on the Density of Receptors Expressed and the Activation of the Inositol Phosphate Cascade. Endocrinology 2005;146:3907-16. characterization of human granulosa cells in stimulated cycles: correlation with oocyte fertilizability. 


\section{Fig. 1 Validation of immunofluorescent labelling}

A. Subtraction of nonspecific binding (red) and auto-fluorescence (green) at $\sim 10^{3}$; granulosa cell. B. Live granulosa cells, unstained control for GHR auto-fluorescence (blue) compared to positive fluorescent signal measurement (box). Gated and removed CD45 positive cells (circle) also confirmed binding specificity (Saizen, Merck Serono, Australia). C. Live human granulosa cells with positive fluorescence for GH receptor (a \& b), and pre-absorbed GH for negative control and binding specificity of GHR (c \& d). Bar $10 \mu \mathrm{m}$.

\section{Fig. 2 Granulosal GHR density and ovarian reserve depletion.}

GHR expression density on granulosa cells collected from patients during IVF treatment with a range of ovarian reserves of follicles, A. 23-30 y patient group, B. 31-34 y patient group, C. 35-38 y patient group, D. $39+$ y patient group. Ovarian reserve was measured indirectly by the antral follicle count (AFC). AFC is the number of follicles between 2-10 mm on day 2-5 of a cycle. Mean fluorescent intensity (MFI) was obtained using an average of $\sim 8000$ granulosa cells per follicle for the direct measurement of receptor protein expression. The number within the column represents the number of follicles analysed for that group. The data were subjected to statistical verification using one-way ANOVA with an uncorrected Fisher's LSD for follicular size. Values in graphs are means \pm S.E.M., and differences were considered significant if $* \mathrm{p}<0.05$, $* * \mathrm{p}<0.01$ and $* * * \mathrm{p}<0.005$.

\section{Fig. 3 Follicle size and the granulosa cell density of GHR, FSHR, BMPR1B and LHR in poor response $39+$ y patients co-treated with $\mathbf{G H}$}

Follicles of different sizes were individually collected and analysed. Granulosa receptor density during an IVF cycle with or without GH co-treatment was measured by flow cytometry. A. GHR, B. FSHR, C. LHR and D. BMPR1B. The number within the column represents the number of follicles analysed for that follicle size. Inset A Combined follicles of different sizes-GHR. Inset B FSHR, Inset C LHR, and Inset D. The number within the column represents the number of follicles analysed. Ovarian reserve measured indirectly by the antral follicle count (AFC). AFC is the number of follicles between 2-10 mm on day 2-5 of a cycle. Mean fluorescent intensity (MFI) was obtained using an average of $\sim 8000$ granulosa cells per follicle for the direct measurement of receptor protein expression. The data were subjected to statistical verification using one-way ANOVA with an uncorrected Fisher's LSD for follicular size. Values in graphs are means \pm S.E.M., and differences were considered significant if $* \mathrm{p}<0.05, * * \mathrm{p}<0.01, * * * \mathrm{p}<0.005$, and $* * * * \mathrm{p}<0.001$.

\section{Fig. 4 GH associated pregnancy and live birth outcome}

A. The effect of GH treatment on pregnancy rate during IVF treatment. B. The effect of GH treatment on pregnancy rate during IVF treatment. The data were subjected to statistical verification using chi square. The chi-square statistic $p$-value is $p=0.0033$. The data were based on the number of embryos transferred per patient age group or treatment, including subsequent frozen embryo cycles (FET). One patient with an ectopic pregnancy (classed as miscarriage) was present in the 23-30 y and the 35-38 y groups. Patients were selected randomly in a prospective regimen. 
Table 1 Patient ovarian reserve, based on antral follicle count (AFC)

$642{ }^{1}$ Typical Ovarian Reserve for age group

$643{ }^{2}$ Ovarian reserve measured indirectly by the Antral Follicle Count (AFC). AFC is the number of follicles

644 between 2-10 mm on day 2-5 of a cycle: group $\mathrm{A}+=30-39$ follicles; group $\mathrm{A}=20-29$

645 follicles; group $\mathrm{B}=13-19$ follicles; group $\mathrm{C}=9-12$ follicles, group $\mathrm{D}=5-8$ follicles; group $\mathrm{E}=\leq 4$ follicles.

646 Follicle count is based on the combined total from both ovaries to determine AFC. The number of follicles aspirated from patients from the specified ovarian reserve group.

${ }^{3}$ CCF-Number of patients with complete failed fertilisation compared to same age group without GH

${ }^{4}$ Percentage per total number of embryos transferred

$650 \quad{ }^{5}$ The average number of oocytes collected at TVOA for the age group

651 a One patient with an ectopic pregnancy (classed as miscarriage)

652 All subsequent frozen embryo cycles (FET) cycles were included in the analysis therefore the data was based 653 on number of embryos transferred.

$654 * * \mathrm{p}=0.003, * \mathrm{p}=0.041$ Chi square test $(\mathrm{d})=+\mathrm{GH} 39+\mathrm{y}$ compared to $(\mathrm{c})=39+\mathrm{y}$ patient groups.

\begin{tabular}{|c|c|c|c|c|c|c|c|c|c|c|c|c|c|c|c|c|}
\hline \multirow[t]{2}{*}{$\begin{array}{c}\text { Age } \\
\text { years }\end{array}$} & \multirow[t]{2}{*}{$\begin{array}{c}\text { IVF } \\
\text { patient }\end{array}$} & \multirow[t]{2}{*}{$\begin{array}{c}\text { Total } \\
\text { follicle }\end{array}$} & \multirow[t]{2}{*}{$\begin{array}{l}\text { Ovarian } \\
\text { reserve }^{1}\end{array}$} & \multicolumn{6}{|c|}{$\begin{array}{l}\text { Ovarian Reserve Group } \\
\text { Number of follicles } \\
\text { collected per group }\end{array}$} & \multicolumn{3}{|c|}{ Oocyte quality } & \multicolumn{4}{|c|}{$\begin{array}{c}\text { Fertility } \\
\mathrm{N}(\%)\end{array}$} \\
\hline & & & & $A+$ & A & B & C & D & $E$ & $\#^{5}$ & $\mathrm{CCF}^{3}$ & ET & Not Pregnant & Pregnant & Miscarriage & $\begin{array}{l}\text { Live } \\
\text { Birth }\end{array}$ \\
\hline $21-30_{a}$ & 10 & 68 & $20-40$ & 26 & 42 & - & - & - & - & 10 & 0 & 12 & $4(33)$ & $8(67)$ & $3(37)$ & $5(42)$ \\
\hline $31-34$ & 12 & 96 & $13-29$ & - & 48 & 23 & 16 & 9 & - & 8 & 0 & 15 & $9(60)$ & $7(47)$ & $1(14)$ & $6(40)$ \\
\hline $35-38 a$ & 12 & 108 & $9-19$ & - & 6 & 46 & 17 & 34 & - & 9 & 0 & 16 & $5(31)$ & $11(68)$ & $5(46)$ & $4(25)$ \\
\hline $39-45$ & 19 & 131 & $3-8$ & - & - & 42 & 5 & 64 & 19 & 7 & 3 & 25 & $22(88)$ & $3\left(12^{c}\right)$ & $2(68)$ & $1\left(4^{c}\right)$ \\
\hline$+\mathrm{GH} 39-45$ & 11 & 48 & $3-8$ & - & - & - & - & 25 & 23 & 4.5 & 3 & 10 & $4(40)$ & $6\left(60^{\mathrm{d}}\right)^{* *}$ & $4(68)$ & $2\left(20^{d}\right)^{*}$ \\
\hline
\end{tabular}


